\title{
Eutrophication of the Dutch Wadden Sea: external nutrient loadings of the Marsdiep and Vliestroom basin ${ }^{*+}$
}

\author{
Henk W. van der Veer, Wim van Raaphorst \& \\ Magda J. N. Bergman \\ Netherlands Institute for Sea Research; P. O. Box 59, 1790 AB Den Burg Texel,
The Netherlands
}

\begin{abstract}
The increasing $\mathrm{P}$ and $\mathrm{N}$ content in the two main tidal basins in the western Dutch Wadden Sea, the Marsdiep and the Vliestroom basin, has been reconstructed from the 50s onwards. The area is enriched with nutrients by two sources both originating from the river Rhine, one being the discharge from Lake IJssel and the other the exchange with the coastal zone of the North Sea. Due to a buffering by Lake IJssel for about 15-20 years, the eutrophication of the western Wadden Sea showed a time lag compared with the continuously increasing nutrient concentrations in the river Rhine and the coastal zone of the North Sea. At present, the primary production in part of the area still seems to be nutrient limited in summer, while loadings have already been decreasing in recent years. So far, no severe, negative effects on the ecosystem have been reported. Some remarks are made on the eutrophication in 'other parts of the Dutch' Wadden Sea in relation to the hydrographic characteristics of these areas.
\end{abstract}

\section{INTRODUCTION}

During the last decades fresh surface waters in western Europe have been enriched considerably with nutrients from land run-off as well as from industrial and domestic waste water discharges. In the Netherlands this has resulted in a dramatic increase in nutrient concentrations in the main surface waters (Anon., 1980). Serious effects such as nuisance-causing blooms of blue-green algae and transparencies of less than $30 \mathrm{~cm}$ in formerly clear waters have been observed (Anon., 1980).

Freshwater run-offs are finally discharged in the marine environment and here, particularly in the coastal zone, eutrophication may also be expected. Part of the Dutch coastal zone consists of estuarine areas, the main one being the Wadden Sea, which is a nursery area for a number of commercially important fish species such as plaice (Zijlstra, 1972; Kuipers, 1978; van der Veer, 1986) and a resting area for wading birds (for a review see Smit \& Wolff, 1983).

Although the nutrient cycling of the Dutch Wadden Sea has been the subject of

- Presented at the VI International Wadden Sea Symposium (Biologische Anstalt Helgoland, Wattenmeerstation Sylt, D-2282 List, FRG, 1-4 November 1988)

+ Publication No. 18 of the project "Ecological Research of the North Sea and Wadden Sea" (EON) 
extensive studies for a long time already (Postma, 1954, 1966, 1985; Duursma, 1961; van Bennekom et al., 1974; Helder, 1974; de Jonge \& Postma, 1974; Rutgers van der Loeff, 1980), a review of the general trend in the nutrient concentrations in the area has never been compiled. The enormous freshwater discharge by Lake IJssel in the western part of the Wadden Sea is expected to enrich especially this estuarine area with nutrients. In recent years an increasing amount of information has become available on effects of eutrophication on primary as well as on secondary production in this area (Beukema \& Cadée, 1986; Cadée, 1986).

This paper describes the eutrophication of the two main tidal basins in the western part of the Dutch Wadden Sea, the Marsdiep and the Vliestroom basin. Eutrophication may be defined according to Postma (1985): "an enrichment with nutrients or organic matter." The ecological effects of an increased loading with nutrients are left out in this definition. Attention is paid mainly to $\mathrm{P}$ and $\mathrm{N}$, because at least in the past these nutrients seemed to have limited primary production (Cadée \& Hegeman, 1974) and the concentrations of both of these nutrients have increased considerably in inland waters during the last few decades. Besides reviewing the nutrient concentrations in the area and of the loadings by the main sources, an attempt has been made to compare the importance of the coastal zone of the North Sea and the discharge from Lake IJssel as sources of P and N. Finally, some remarks are made on the effects of eutrophication on the ecosystem.

\section{MATERIAL AND METHODS}

Figure 1 shows the location of the western part of the Dutch Wadden Sea (henceforth called western Wadden Sea), together with the main nutrient source, the river Rhine, feeding the Wadden Sea via the coastal zone of the North Sea and via discharge from

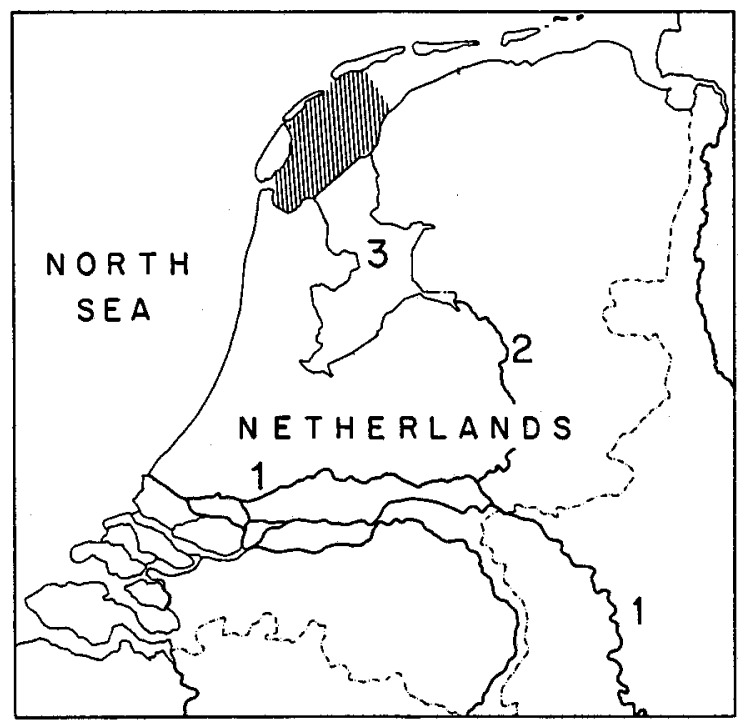

Fig. 1. The western part of the Wadden Sea (shaded), together with Lake IJssel (3), the coastal zone of the North Sea and the two main rivers, Rhine (1) and IJssel (2), feeding the western Wadden Sea indirectly 
Lake IJssel. The synopsis of the development of the eutrophication of the western Wadden Sea has been based upon a compilation of published and unpublished data. In the case of lack of data, an attempt has been made to reconstruct the missing data.

\section{The rivers Rhine and IJssel}

All the information concerning flows and concentrations of $\mathrm{N}$ and $\mathrm{P}$ components of the rivers Rhine and IJssel was obtained from the annual reports of the International Rhine Commission, Koblenz, and from the quarterly reports on the water quality of the Dutch waters as published by Rijkswaterstaat, Rijks Instituut voor Zuivering van Afvalwater (RIZA), Lelystad. However, before 1972 total-N and total-P concentrations were not determined regularly and these values had to be estimated from the ratio $\left(\mathrm{NH}_{4}{ }^{+}+\mathrm{NO}_{3}{ }^{-}\right) /$total $\mathrm{N}$. In river IJssel this ratio was approximately 0.85 during the period 1972-1985 (Fig. 2) and the same has been assumed in the Rhine and the IJssel for the

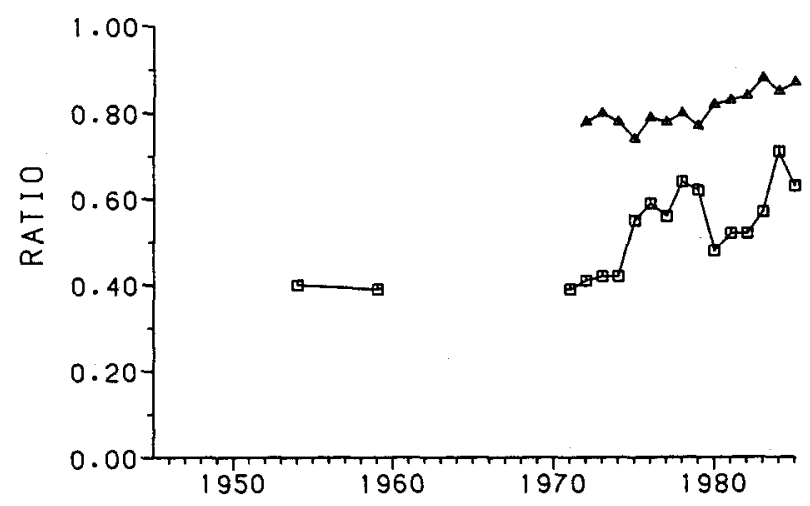

Fig. 2. Ratio between the concentration of $\left(\mathrm{NH}_{4}{ }^{+}+\mathrm{NO}_{3}{ }^{-}\right) /$total- $\mathrm{N}(\Delta)$ and of ortho-P/total-P () in the river IJssel from 1955 onwards

period 1954-1972. Total-P has been estimated from the ratio ortho-P/total-P. Around 1960 (Postma, unpubl.) and in the early 70s, this ratio in the IJssel was about the same, 0.40 (Fig. 2). This value has also been adopted for the intervening years. The uncertainty introduced by this assumption is roughly estimated at $10 \%$. From the 70 s onwards, this ratio has increased to values of approximately 0.75 .

\section{Discharge of Lake IJssel}

Data on the monthly discharges of fresh water from Lake IJssel into the Wadden Sea were obtained from Rijkswaterstaat Directie Zuiderzeewerken, Lelystad. Data on the concentrations of $\mathrm{N}$ and $\mathrm{P}$ components near the sluices (location $\mathrm{Y} 1$ and $\mathrm{Y} 2$ ) were published in the quarterly reports of RIZA from 1972 onwards. Ortho-P and total-P were measured from 1949 to 1951 by Postma (1954), in 1957 by Duursma (1961), in 1958-1959 by Postma (1967 and unpubl.) and during 1967 to 1970 by de Kloet (1971). Data concerning $\mathrm{N}$ components were determined in $1957\left(\mathrm{NH}_{4}{ }^{+}\right)$by Duursma (1961), in 1960-1962 $\left(\mathrm{NH}_{4}{ }^{+}, \mathrm{NO}_{3}{ }^{-}\right.$, total-N) by Postma (1966), and in 1971-1972 $\left(\mathrm{NH}_{4}{ }^{+}, \mathrm{NO}_{3}{ }^{-}\right)$by 
Helder (1974). Based on the ratio between the concentrations at Andijk and near the sluices in 1972-1985 (Rijkswaterstaat), data of total- $\mathrm{N}$ from near Andijk (Governmental Water Company, unpublished) for the period 1966-1972 were converted into concentrations near the sluices by multiplying by 0.90 . The possible error in this factor is about $20 \%$. Missing data of total-N for the period before 1966 were estimated by extrapolation from measured ratios between total- $\mathrm{N}$ and total-P in later years (Table 1). Overall, this results in a level of uncertainty in the reconstructed data of approximately $35 \%$.

Table 1. Ratio between total- $\mathrm{N}$ and total-P in the northern part of Lake IJssel for a number of years, extrapolated from measurements in the intervening years (for further explanation see text)

\begin{tabular}{|ccccc|}
\hline & & \multicolumn{2}{c|}{ Quarter } & 4 \\
\hline $1949-1951$ & 2 & 3 & 25 \\
$1958-1959$ & 25 & 35 & 25 & 35 \\
$1960-1962$ & 25 & 35 & 35 & 22 \\
$1966-1967$ & 22 & 22 & 22 & 18 \\
$1970-1971$ & 20 & 23.5 & 15 & \\
\hline
\end{tabular}

\section{The coastal zone of the North Sea}

Nutrient data for the coastal zone of the North Sea were obtained from the quarterly reports of RIZA for a location off Calantsoog (C2 and C4) from 1973 onwards. Ortho-P has been measured from 1973 onwards. Older data wẹre only available for the period 1949-1951 (Postma, 1954) and 1958-1959 (Duursma, 1961) near lightvessel Texel. It was assumed that at this location the concentrations were 1.3 times lower than those at $\mathrm{C} 2$ and C4 (de Wit et al., 1982). The uncertainty in this conversion is approximately $25 \%$. For total-P, data were available only for the period 1975-1982. Based on the ratio ortho-P/ total-P during this period, the ratio for the other years was estimated and missing data for total-P were calculated (Table 2). The ratios for the period 1949-1959 could only be calculated very roughly. Data about $\mathrm{NH}_{4}{ }^{+}$and $\mathrm{NO}_{3}{ }^{-}$were available from 1975 onwards from the quarterly reports of the RIZA and for the period 1960-1962 (Postma, 1966) near lightvessel Texel. For $\mathrm{N}$, the concentrations at this station were estimated to be 1.7 times lower than those at $\mathrm{C} 2$ and $\mathrm{C} 4$ (de Wit et al., 1982), with an uncertainty of $25 \%$. Total-N

Table 2. Ratio between ortho-P and total-P in the coastal zone of the North Sea (C2 and C4), extrapolated from measurements in the intervening years (for further explanation see text)

\begin{tabular}{|c|c|c|c|c|}
\hline & \multicolumn{4}{|c|}{ Quarter } \\
\hline & 1 & 2 & 3 & 4 \\
\hline $1949-1951$ & 0.50 & 0.25 & 0.25 & 0.50 \\
\hline $1958-1959$ & 0.50 & 0.25 & 0.25 & 0.50 \\
\hline 1973 & 0.30 & 0.30 & 0.30 & 0.50 \\
\hline $1983-1985$ & 0.40 & 0.25 & 0.55 & 0.55 \\
\hline
\end{tabular}


was only measured in 1960-1962 (Postma, 1966) and between 1975-1982 (RIZA). Based on the ratio $\left(\mathrm{NH}_{4}{ }^{+}+\mathrm{NO}_{3}{ }^{-}\right) /$total-N during these years the ratio has been extrapolated for the years 1983-1985 (Table 3), from which total-N could be estimated. For the period before 1960 and between 1962-1973 total-N was estimated in a similar way (Table 4). The final level of uncertainty in the reconstructed data is in the order of $50 \%$.

Table 3. Ratio between $\left(\mathrm{NH}_{4}^{+}+\mathrm{NO}_{3}^{-}\right)$/total- $\mathrm{N}$ in the coastal zone of the North Sea (C2 and C4), extrapolated from measurements in the period 1975-1982 (for further explanation see text)

\begin{tabular}{|ccccc|}
\hline & 1 & 3 & Quarter & 4 \\
\hline $1983-1985$ & 0.70 & 0.35 & 0.35 & 0.70 \\
\hline
\end{tabular}

Table 4. Ratio between total-N and total-P in the coastal zone of the North Sea (C2 and C4), extrapolated from measurements in the intervening years (for further explanation see text)

\begin{tabular}{|lllll|}
\hline & & & Quarter & \\
& 1 & 2 & 3 & 4 \\
\hline $1949-1951$ & 8 & 8 & 5.5 & 5.5 \\
$1958-1959$ & 8 & 8 & 5.5 & 5.5 \\
$1960-1962$ & 8 & 8 & 5.5 & 5.5 \\
1973 & 8 & 8 & 5.5 & 5.5 \\
\hline
\end{tabular}

\section{The western Wadden Sea}

Data on nutrient concentrations in the western Wadden Sea are available from 1972 onwards from the quarterly reports of the RIZA. Older data of $\mathrm{P}$ components are available for the period 1970-1971 (ortho-P) by de Jonge \& Postma (1974), and for the period 1949-1951 (ortho-P and total-P) by Postma (1954). N components are presented for 1970-1971 $\left(\mathrm{NH}_{4}{ }^{+}\right.$and $\left.\mathrm{NO}_{3}{ }^{-}\right)$measured by Helder (1974), for $1960-1962\left(\mathrm{NH}_{4}{ }^{+}, \mathrm{NO}_{3}{ }^{-}\right.$and total-N) by Postma (1966). Based on the ratios between total- $\mathrm{N}$ and total-P in these years (Table 5), missing data on total-N and total-P were reconstructed, with an estimated error of approximately $40 \%$.

Table 5. Ratio between total- $\mathrm{N}$ and total-P in the western Wadden Sea, extrapolated from measurements in the intervening years (for further explanation see text)

\begin{tabular}{|c|c|c|c|c|}
\hline & \multicolumn{4}{|c|}{ Quarter } \\
\hline & 1 & 2 & 3 & 4 \\
\hline $1949-1951$ & 15 & 15 & 12.5 & 12.5 \\
\hline $1960-1962$ & 15 & 15 & 12.5 & 12.5 \\
\hline $1970-1971$ & 15 & 15 & 12.5 & 12.5 \\
\hline
\end{tabular}



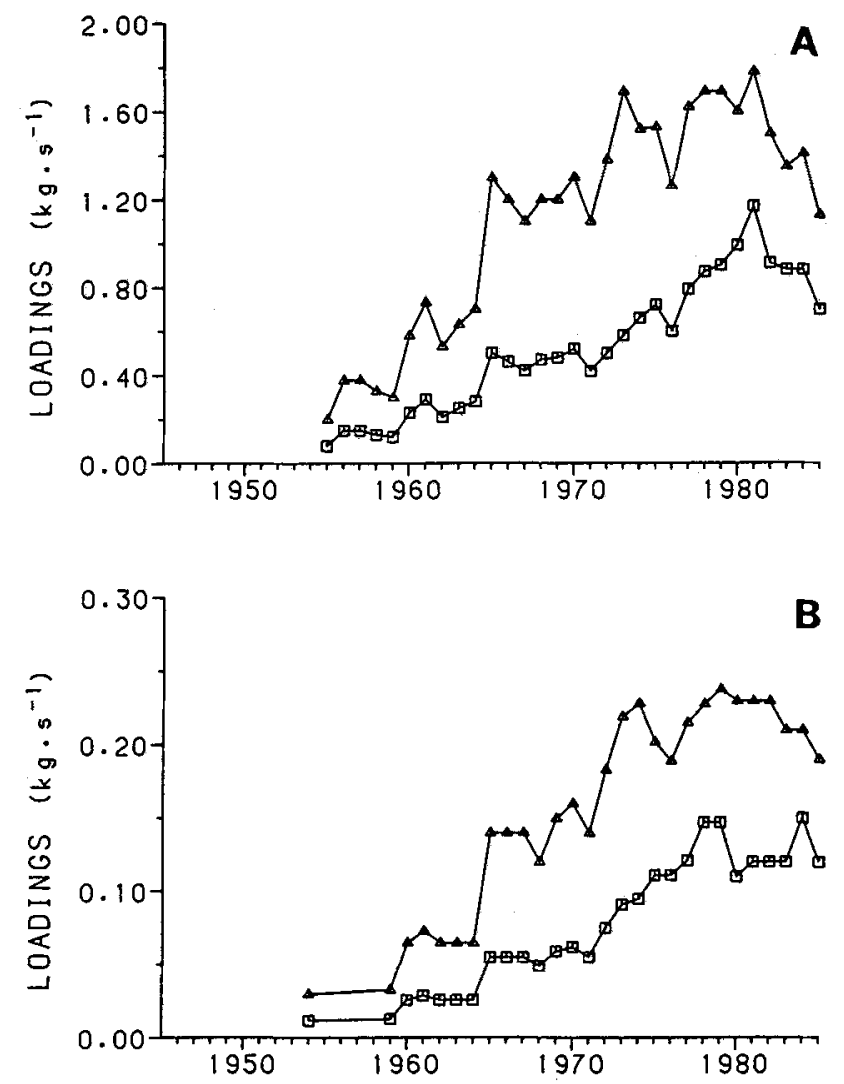

Fig. 3. Loadings of ortho-P (ㅁ) and total-P ( $\Delta)$ in $\mathrm{kg} \mathrm{sec}^{-1} ; \mathrm{A}$ : the river Rhine near Lobith; $B$; the river IJssel near Kampen

\section{RESULTS}

The rivers Rhine and IJssel

The concentrations of nutrients in the rivers Rhine and IJssel are multiplied by the water flows to calculate the yearly mean loadings. Both total-P (Fig. 3) and total-N (Fig. 4) showed a continuous increase from 1954 onwards. In 1981, the loadings had increased 5-7 times for total-P and 2-3 times for total- $\mathrm{N}$, compared with 1954. Ortho-P and $\mathrm{NO}_{3}{ }^{-}$ showed an even stronger increase. From 1981 to 1985 , mean loadings decreased by about $20-30 \%$. This was not caused by differences in river flow but was merely due to reduced nutrient concentrations.

\section{Discharge of Lake IJssel}

The discharge from Lake IJssel into the Wadden Sea is given in Figure 5. From 1950 until 1981 there was an increase in total-P from 0.03 to $0.16 \mathrm{~kg} \mathrm{~s}^{-1}$, and in total- $\mathrm{N}$ from 0.8 to $2.3 \mathrm{~kg} \mathrm{~s}^{-1}$. From 1981, the discharge of total-N has stabilized, while total-P showed a 

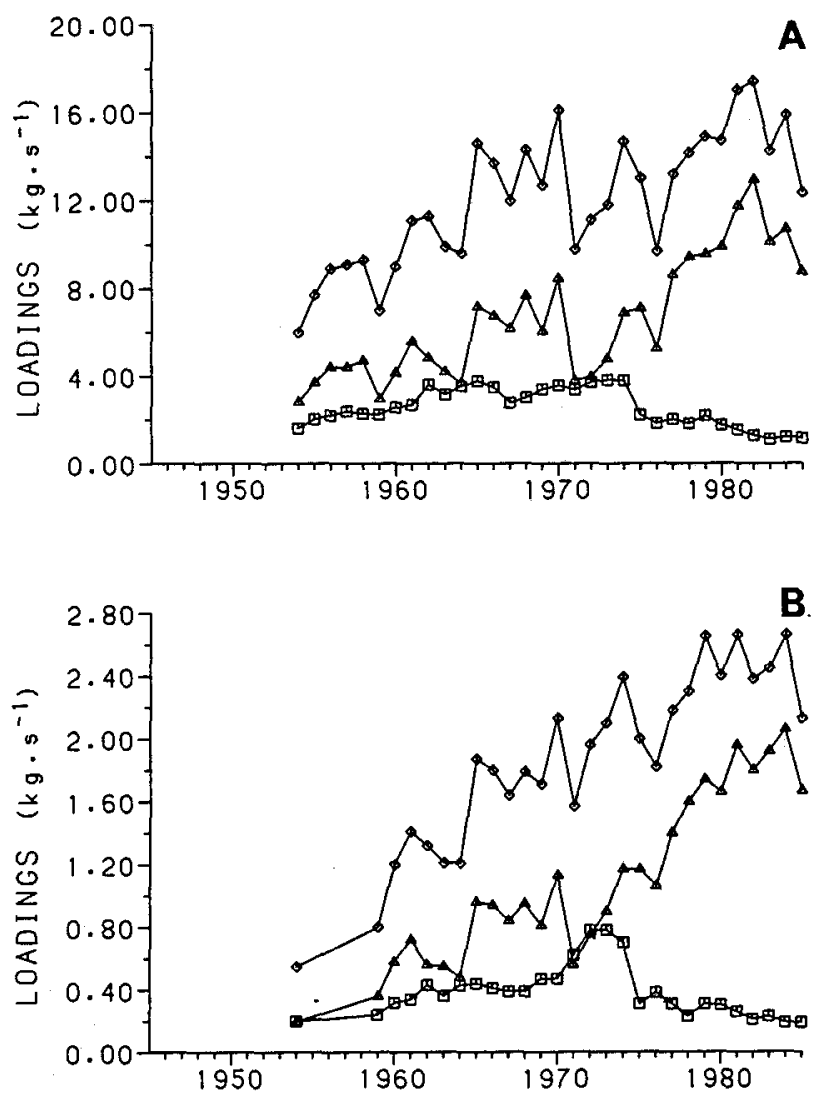

Fig. 4. Loadings of total-N $(\diamond), \mathrm{NO}_{3}{ }^{-}(\Delta)$ and $\mathrm{NH}_{4}{ }^{+}(\square)$ in $\mathrm{kg} \mathrm{sec}^{-1}$; A: the river Rhine near Lobith; $\mathrm{B}$ : the river IJssel near Kampen.

slight decrease, with a similar amount of fresh water discharged through the sluices during that period (1981-1985). The increase in the nutrient loadings in the discharges mainly took place from 1970 onwards, which is in contradiction with the situation at the inflow of the lake, the river IJssel (see Figs 3 and 4).

\section{The coastal zone of the North Sea}

Figure 6 shows the nutrient concentrations in the coastal zone of the North Sea in the first and third quarter of the year. Since only few data were available and most had to be reconstructed the overall level of uncertainty is high. It seems most likely that a continuous increase in both the concentrations of total-P and total-N took place from 1950 onwards until 1980 and a stabilization thereafter. From 1950 to 1985 total-P increased by approximately a factor of 7 and total- $\mathrm{N}$ by approximately a factor of 5 . The other quarters of the year showed a similar pattern. Based on annual mean concentrations, total-P and total- $\mathrm{N}$ have increased by approximately a factor of 4 during the period 1950 to 1985 . 


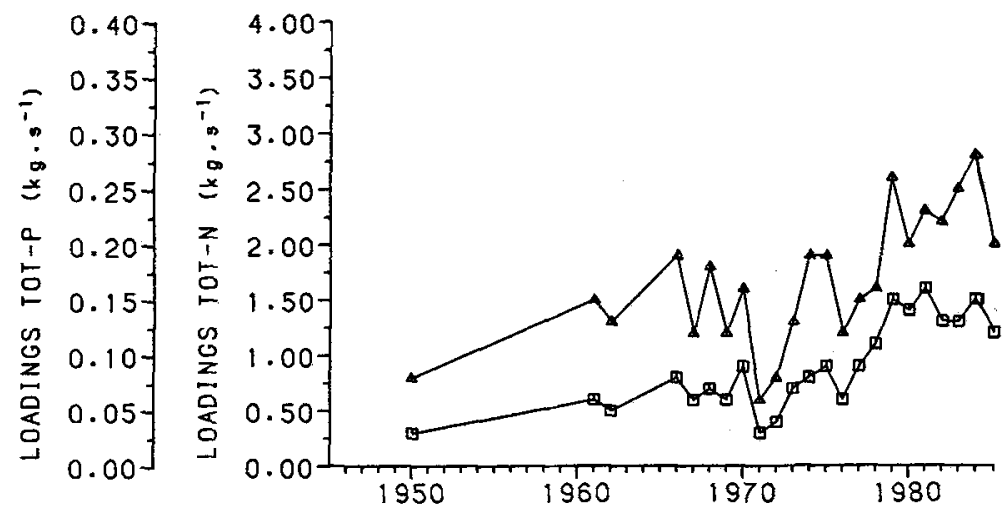

Fig. 5. Loadings of total-P $(\square)$ and total-N $(\Delta)$ in the discharges of Lake IJssel $\left(\mathrm{kg} \mathrm{sec}^{-\mathbf{1}}\right)$
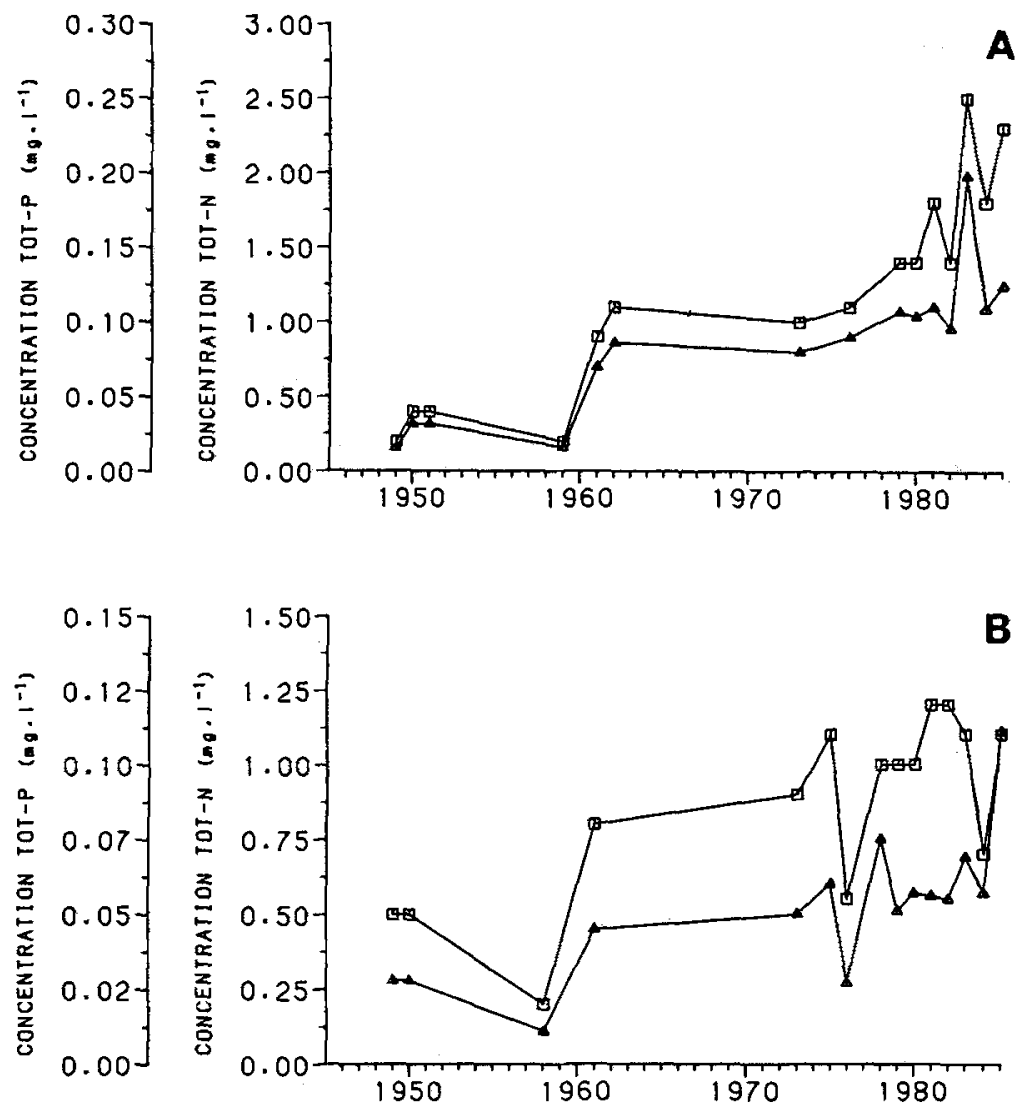

Fig. 6. Concentrations of total-N $(\Delta)$ and total-P (ㅁ) in the coastal zone of the North Sea near Callantsoog ( $\mathrm{mg} \mathrm{l}^{-1}$ ); A: first quarter of the year; B: third quarter of the year 


\section{The western Wadden Sea}

The nutrient concentrations in the western Wadden Sea are presented in Figures 7 and 8 for the first quarter of the year, and in Figures 9 and 10 for the third quarter. The differences in concentrations between the various locations seemed to be rather small compared with the variations in time. In general, the pattern proved to be about the same in the whole area, with lowest concentrations near the tidal inlets of the area, especially in the Vliestroom. The increase in the concentrations of P components from 1950 onwards
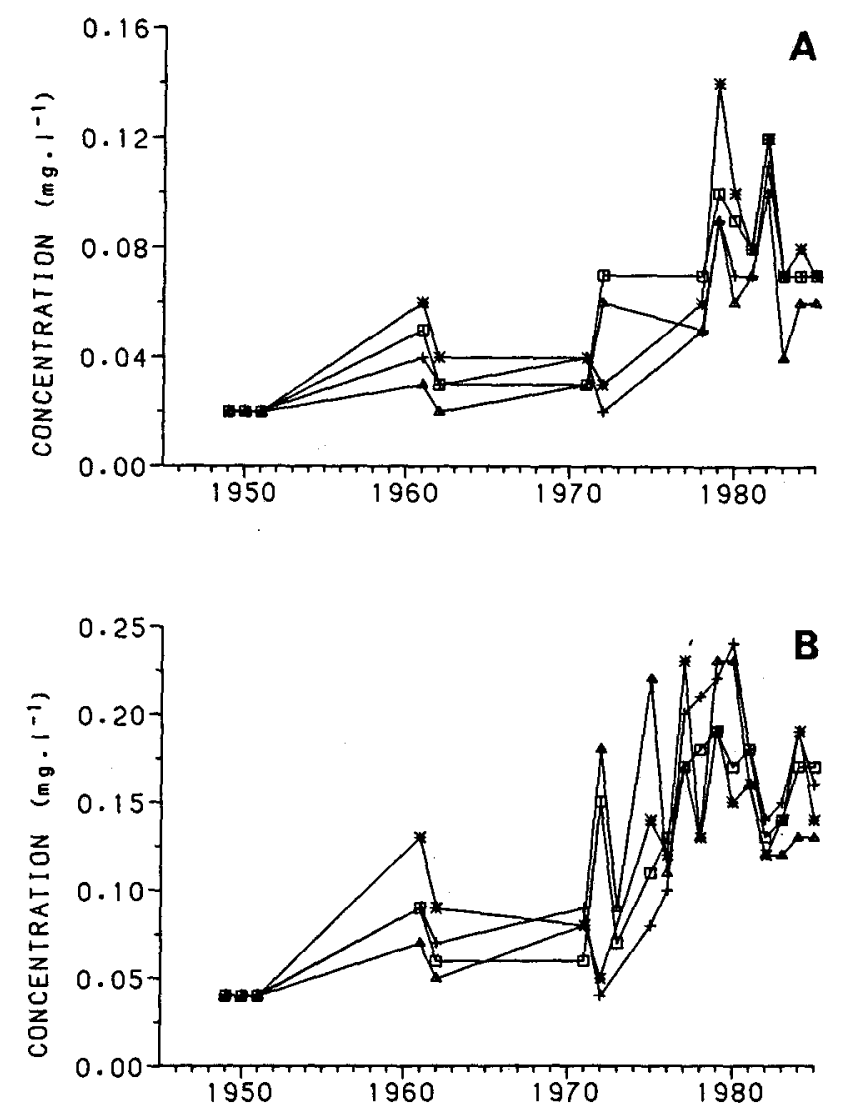

Fig. 7. Concentrations of $P$ components $\left(\mathrm{mg} \mathrm{l}^{-1}\right)$ in the western Dutch Wadden Sea: Marsdiep inlet () , Vliestroom inlet $(\Delta)$, Blauwe Slenk $(+)$ and Doove Balg (*⿻丷木) during the first quarter of the year; A: ortho-P; B: total-P

seemed to be much larger than that of the $N$ components. In the third quarter the $N$ components showed hardly any increase at all. A main part of the increase in nutrient concentrations took place between about 1970 and 1980. During the last few years concentrations seem to have dropped somewhat. Between 1950 and 1980, ortho-P and total-P increased respectively by a factor of $5-6$ and $3-6$ in the first and third quarters. For $\mathrm{N}$, the increase was much lower and depended on the season: in the first quarter about 2 

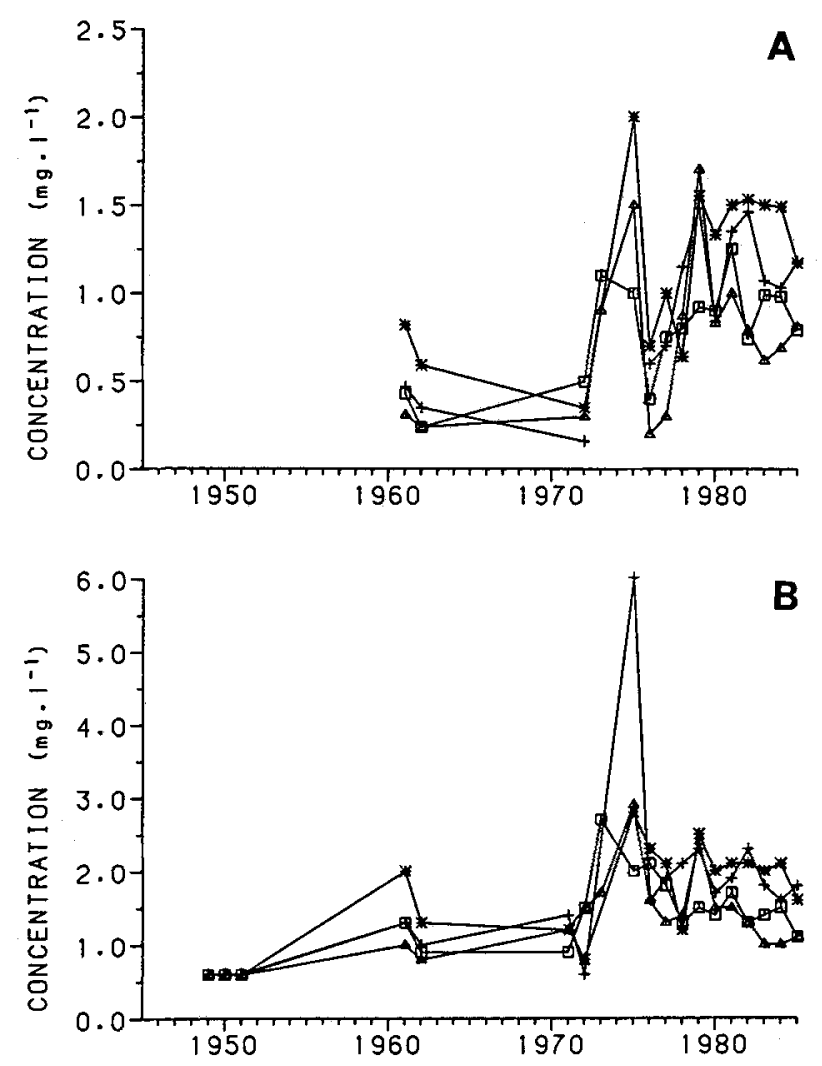

Fig. 8. Concentrations of $N$ components $\left(\mathrm{mg} \mathrm{l}^{-1}\right)$ in the western Dutch Wadden Sea: Marsdiep inlet $(\square)$, Vliestroom inlet $(\Delta)$, Blauwe Slenk $(+)$ and Doove Balg (*) during the first quarter of the year; A: $\mathrm{NO}_{3}{ }^{-}$; B: total-N

times, in the third quarter hardly any increase at all. The general trend during the other quarters of the year is the same: a large increase between 1970 and 1980 , followed by a small decrease in the most recent years.

\section{DISCUSSION}

Recently, Postma (1985) reviewed the eutrophication of Dutch inshore and some coastal waters (Ems-estuary). However, he did not present a detailed analysis of the increase in nutrient loadings and concentrations. Due to the strong influence of the river Rhine in the western Wadden Sea, it was expected that this area would be more affected by an increased loading with nutrients than the eastern part of the Wadden Sea. Inflow of fresh water from the Rhine takes place in two ways, but it does not occur directly. One source is the discharge of Lake IJssel, which to a great extent is fed by fresh water from the river IJssel, a branch of the Rhine. The other source is the import of saline coastal water through the tidal inlets which also consists partly of fresh water from the Rhine transported along the coastal zone (van Bennekom et al., 1974; Zimmerman, 1976). 

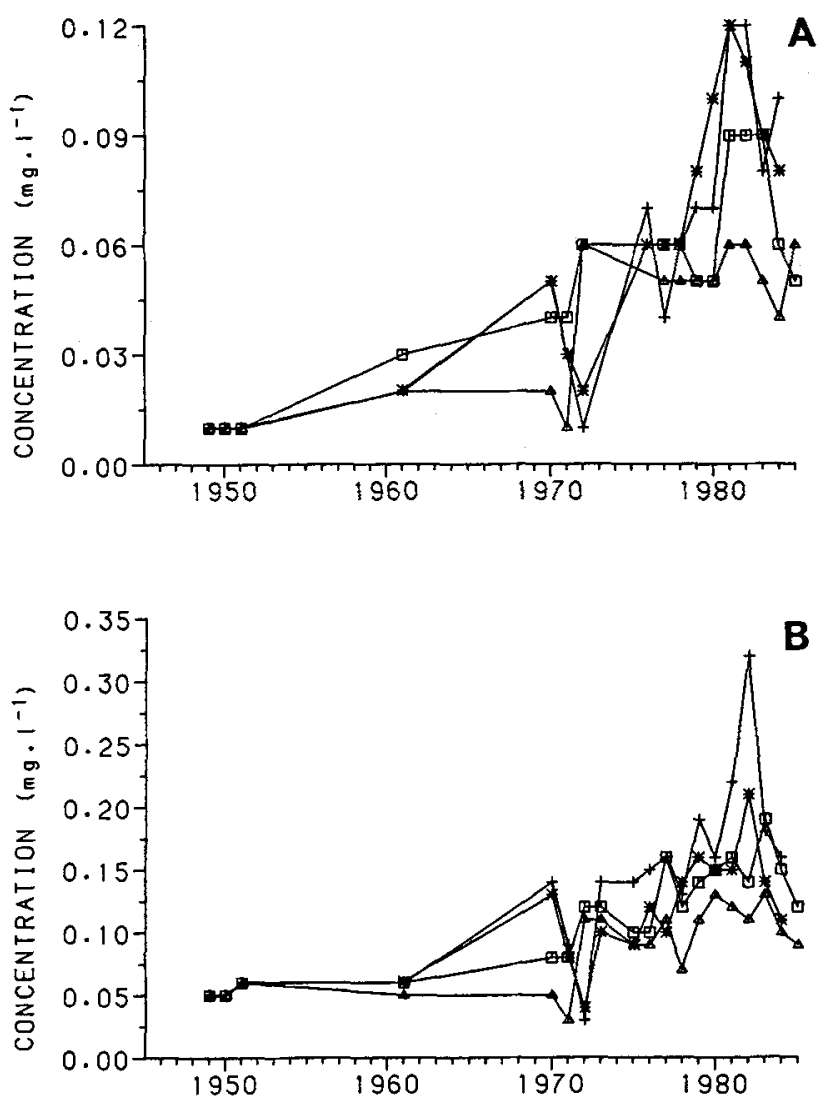

Fig. 9. Concentrations of $P$ components $\left(\mathrm{mg} \mathrm{l}^{-1}\right)$ in the western Dutch Wadden Sea: Marsdiep inlet (ㅁ), Vliestroom inlet $(\Delta)$, Blauwe Slenk $(+)$ and Doove Balg (**) during the third quarter of the year; A: ortho-P; B; total-p

The reconstruction of the nutrient concentrations in the area and the loadings of the main sources is hampered by lack of data especially from the past. Therefore, a partial reconstruction has been made by interpolation and extrapolation of the missing observations. This procedure results in uncertainties in the order of 30 to $50 \%$. Particularly the data of the period before 1970 should be treated with some reservation. A comparison of the nutrient loadings from the sources with the resulting concentrations in the western Wadden Sea reveals some striking facts. Although rather strong year-to-year fluctuations in nutrient concentrations and loadings occurred, clear trends can be observed.

The increase in the nutrient content of the river Rhine seemed to be a rather continuous process during the period 1950-1980, followed by a slight decrease in recent years. The same pattern could be observed in the coastal zone of the North Sea, which is directly enriched by inflow from the Rhine. The river IJssel, feeding Lake IJssel, showed a similar increase in nutrient loading in the course of time. However, in the discharge of Lake IJssel there seemed to be a time lag. Until about 1970, loadings remained the same, and an increase could only be observed between 1970 and 1980. This suggests that for at 

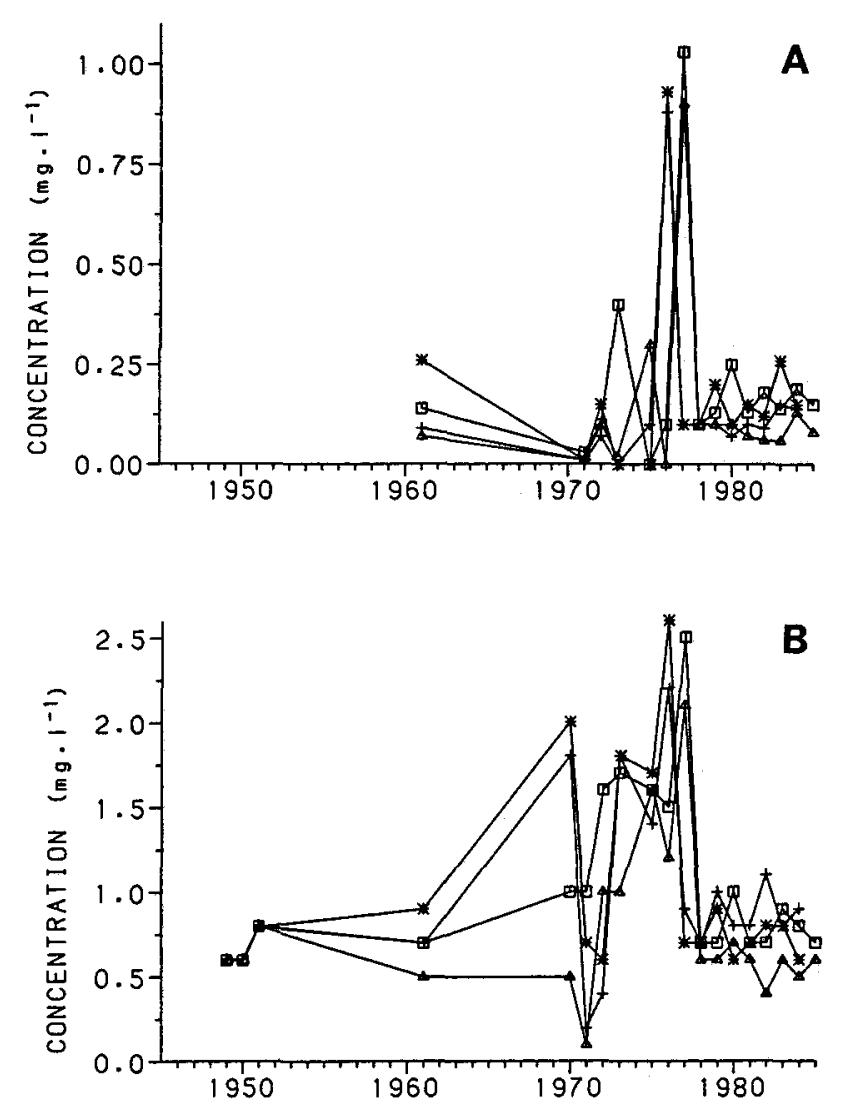

Fig. 10. Concentrations of $\mathrm{N}$ components $\left(\mathrm{mg} \mathrm{l}^{-1}\right)$ in the western Dutch Wadden Sea: Marsdiep inlet $(\square)$, Vliestroom inlet $(\Delta)$, Blauwe Slenk $(+)$ and Doove Balg $(*)$ during the third quarter of the year; A: $\mathrm{NO}_{3}{ }^{-}$; B: total-N

least 15-20 years, Lake IJssel acted as a trap for the nutrient loadings from the river IJssel. This pattern of nutrient concentrations in the discharge of Lake IJssel was also found in the western Wadden Sea. A similar time lag of at least 15 years could be observed before an increase in concentrations started around 1970. During the past 5 years even a decrease in nutrient concentrations occurred. The correspondence between the development of the nutrient levels in the western Wadden Sea and the nutrient discharges of Lake IJssel suggests that these loadings from Lake IJssel are the main nutrient source of the western Wadden Sea, rather than import from the coastal zone of the North Sea. This conclusion is in contradiction with the suggestions made by Postma (1954) and de Jonge \& Postma (1974), who stressed the importance of import from the coastal zone as a source of organic matter and associated P components. Reappraisal of their figures by Cadée (1980) and de Wilde \& Beukema (1984) resulted in about an equal importance of Lake IJssel and the coastal zone as sources of organic matter for the western Wadden Sea in the $80 \mathrm{~s}$. However, all these conclusions are based on budget calculations made for only a few years. Due to the strong year-to-year fluctuations, their 
conclusions might be true for these years, but considering the long-term trends, it seems most likely that, in general, Lake IJssel is the main source of nutrients for the western Wadden Sea.

Hardly any measurements on nutrients and primary production were performed before 1965. This means that for most Dutch inshore and coastal waters the effect of increased nutrient levels on primary production cannot be followed over the whole period of eutrophication, as already stated by Postma (1985). However, because of the buffering of Lake IJssel, this situation does not hold for the western Wadden Sea. Here, eutrophication essentially started from about 1970 onwards, while the first measurements of primary production were already made during the period 1963-1966 (Postma \& Rommets, 1970) and 1972-1973 (Cadée \& Hegeman, 1974). So, apart from methodical problems related to the measurements of production, the figures from Postma \& Rommets (1970) and Cadée \& Hegeman (1974) may be considered as baseline levels. On the basis of their measurements of pelagic primary production, Cadée \& Hegeman (1974) concluded that in spite of the high turbidity of the Wadden Sea, a nutrient limitation in summer could not be excluded in part of the area. In winter, nutrient limitation did not seem to occur in these years.

In these parts of the Wadden Sea an increased nutrient loading may have resulted in a lengthening of the period of non-nutrient limitation and probably in an increased production. Although there are not enough monthly production figures, the above suggestion is strongly supported by annual production figures measured over a number of years (Table 6). Not only the data for the Marsdiep tidal inlet area (as reviewed by

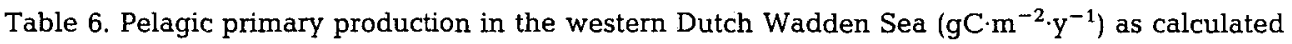
from data of different authors from 1963 onwards. All measurements were done in deep gullies;

${ }^{1}$ Marsdiep tidal inlet; ${ }^{2}$ inner part of the area

\begin{tabular}{|lcl|}
\hline Year & Production & Reference \\
\hline $1964-1966$ & $120^{2}-170^{1}$ & Postma \& Rommets (1970) \\
& $92.5^{2}-151.5^{1}$ & Cadée \& Hegeman (1974) \\
$1972-1973$ & $150^{2}-200^{1}$ & Cadée \& Hegeman (1974) \\
& $135^{2}-145^{1}$ & Cadée \& Hegeman (1979) \\
$1974-1975$ & $340^{1}$ & Cadée \& Hegeman (1979) \\
$1981-1982$ & $165^{2}-303^{1}$ & Cadée (1986) \\
1986 & & Veldhuis et al. (1988) \\
\hline
\end{tabular}

Cadée, 1986) but also the production in other parts of the western Wadden Sea have increased from $100-150 \mathrm{gC} . \mathrm{m}^{-2} \cdot \mathrm{y}^{-1}$ in 1970 to $165-300$ in 1986 . However, Cadée (1986) mentioned a discrepancy between eutrophication and the timing in increase of primary production, but he considered ortho-P as indicator for the state of eutrophication instead of total-P. Although ortho-P did show an increase from 1950 onwards, total-P remained approximately constant. The increase in ortho-P therefore illustrated a shift between $P$ components and a shift from P-limitation to most likely N-limitation at least during parts of the year (Veldhuis et al., 1988). The increase of ortho-P in the period 1950-1970 as observed by de Jonge \& Postma (1974) and mentioned by Cadée (1986) therefore does not necessarily mean a severe increase in the amount of nutrients available for primary 
production. According to the present data such an increase most likely started after 1970 , approximately at the same time as the increase in primary production as observed by Cadée (1986). The increased annual production indicates a narrowing of the period of nutrient limitation during the year, but still in the present situation Veldhuis et al. (1988) suggest a nutrient limitation during the summer period. So although the area has become more eutrophic over the years, the western Wadden Sea seems to be nutrient limited during part of the year.

The increase in annual primary production may have resulted in an enlarged food supply for the consumers over the year and may also have an impact on the functioning of the ecosystem as far as this increased food supply is not exported towards the North Sea. Cadée \& Hegeman (1986) suggest an increase in the Phaeocystis abundance and Beukema \& Cadée (1986) found a doubling of both biomass and annual production of the macrozoobenthos living on the tidal flats in the western Wadden Sea during 1970-1984. An impact on the functioning of the ecosystem is difficult to detect. So far, severe negative effects of eutrophication have not been reported, and low oxygen conditions over longer periods seem to occur only locally (Tijssen \& van Bennekom, 1976; van der Veer \& Bergman, 1986).

Eutrophication of the western Wadden Sea seems to be determined by the loadings of Lake IJssel and because of the buffering of nutrients by the lake, eutrophication of the western Wadden Sea has been delayed for quite a long time, i.e. some 15 years compared to the sources of the nutrients, the river Rhine. It might be stated that other parts of the Dutch Wadden Sea with a freshwater run-off directly into the estuary, such as the Ems-Dollard estuary, may show a more continuous increase in nutrient concentrations from the 50s onwards. Areas without any significant input of fresh water will only be influenced by exchange with the coastal zone of the North Sea. These areas will also show a pattern of a continuous increase, though on a rather low level, because of the relatively low loadings coming from the North Sea. To confirm these hypotheses a more detailed analysis of the nutrient concentrations in these areas is necessary.

Acknowledgement. Thanks are due to G. C. Cadée for critical reading of the manuscript.

\section{LITERATURE CITED}

Anonymous, 1980. Ontwikkeling van grenswaarden voor doorzicht, chlorophyl, fosfaat en stikstof. Resultaten van de tweede eutrofiëringsenquete. Coördinatiecommissie uitvoering wet verontreiniging oppervlaktewateren, werkgroep VI, $48 \mathrm{pp}$.

Bennekom, A. J. van, Krijgsman-van Hartingsveld, E., Veer, G. C. M. van der \& Voorst, H. F. J van, 1974. The seasonal cycle of reactive silicate and suspended diatoms in the Dutch Wadden Sea. Neth. J. Sea Res. 8, 359-374.

Beukema, J. J. \& Cadée, G. C., 1986. Zoobenthos responses to eutrophication of the Dutch Wadden Sea. - Ophelia 26, 55-65.

Cadée, G. C., 1980. Reappraisal of the production and import of organic carbon in the western Wadden Sea. - Neth. J. Sea Res. 14, 305-322.

Cadée, G. C., 1986. Increased phytoplankton primary production in the Marsdiep area (western Dutch Wadden Sea). - Neth. J. Sea Res. 20, 285-290.

Cadée, G. C. \& Hegeman, J., 1974. Primary production of phytoplankton in the Dutch Wadden Sea. Neth. J. Sea Res. 8, 240-259.

Cadée, G. C. \& Hegeman, J., 1979. Phytoplankton primary production, chlorophyll and composition in an inlet of the western Wadden Sea (Marsdiep). - Neth. J. Sea Res. 13, 224-241. 
Cadée, G. C. \& Hegeman, J., 1986. Seasonal and annual variation in Phaeocystis pouchetii (Haptophyceae) in the westernmost inlet of the Wadden Sea during the 1973 to 1985 period - Neth. J. Sea Res. 20, 29-36.

Duursma, E. K., 1961. Dissolved organic carbon, nitrogen and phosphorus in the sea. - Neth. J. Sea Res. 1, 1-148.

Helder, W., 1974. The cycle of dissolved inorganic nitrogen compounds in the Dutch Wadden Sea. Neth. J. Sea Res. 8, 154-173.

Jonge, V. N. de \& Postma, H., 1974. Phosphorus compounds in the Dutch Wadden Sea. - Neth. J. Sea Res. 8, 139-153.

Kloet, W. A. de, 1971. Het eutrofiëringsproces in het IJsselmeergebied. - Meded. Hydrobiol. Res. 5, 23-28.

Kuipers, B. R., 1978. Opname en gebruik van voedsel door de jonge schol (Pleuronectes platessa L.) in een getijdengebied. Thesis Univ. Amsterdam $91 \mathrm{pp}$.

Postma, H., 1954. Hydrography of the Dutch Wadden Sea. - Archs. néerl. Zool. 10, 405-511.

Postma, H., 1966. The cycle of nitrogen in the Wadden Sea and adjacent areas. - Neth. J. Sea Res. 3, 186-221.

Postma, H., 1967. Observations on the hydrochemistry of inland waters in the Netherlands. In: Chemical environment in the aquatic habitat. Ed. by H. L. Golterman \& R. S. Clymo, North Holland Publ. Comp., Amsterdam, 30-38.

Postma, H., 1985. Eutrophication of Dutch coastal waters. - Neth. J. Zool. 35, 348-359.

Postma, H. \& Rommets, J. W., 1970. Primary production in the Wadden Sea. - Neth. J. Sea Res. 1, $148-190$

Rutgers van der Loeff, M. M., 1980. Time variation in interstitial nutrient concentrations at an exposed subtidal station in the Dutch Wadden Sea. - Neth. J. Sea Res. 14, 123-143.

Smit, C. J. \& Wolff, W. J., 1983. Birds of the Wadden Sea. In: Ecology of the Wadden Sea. Ed. by W. J. Wolff. Balkema, Rotterdam, 2, 6/1-6/308.

Tijssen, S. B. \& Bennekom, A. J. van, 1976. Lage zuurstofgehaltes in het water op het Balgzand. $\mathrm{H}_{2} \mathrm{O} 9,28-31$.

Veer, H. W. van der, 1986. Regulation of the population of O-group plaice (Pleuronectes platessa L.) in the Wadden Sea. Thesis, Rijksuniv. Groningen, $91 \mathrm{pp}$.

Veer, H. W. van der \& Bergman, M. J. N., 1986. Development of tidally related behaviour of a newly settled O-group plaice (Pleuronectes platessa) population in the western Wadden Sea. - Mar. Ecol. Prog. Ser. 31, 121-129.

Veldhuis, M. J. W., Colijn, F., Venekamp, L. A. H. \& Villerius, L., 1988. Phytoplankton primary production and biomass in the western Wadden Sea (the Netherlands): a comparison with an ecosystem model. - Neth. J. Sea Res. 22, 37-49.

Wilde, P. A. W. J. de \& Beukema, J. J., 1984. The role of zoobenthos in the consumption of organic matter in the Dutch Wadden Sea. - Publ. Ser. Neth. Inst. Sea Res. 10, 145-158.

Wit, J. A. W. de, Schotel, F. M. \& Bekkers, L. E. J., 1982. De waterkwaliteit van de Waddenzee. RIZA nota 82-065, 1-67.

Zimmerman, J. T. F., 1976. Mixing and flushing of tidal embayments in the western Dutch Wadden Sea. Part I. Distribution of salinity and calculation of mixing time scales. - Neth. J. Sea Res. 10 , $149-191$.

Zijlstra, J. J., 1972. On the importance of the Waddensea as a nursery area in relation to the conservation of the southern North Sea fishery resources. - Symp. zool. Soc. London. 29, 233-258. 